\title{
Avoiding mastoid cavity Problems: Mastoid obliteration using Bioactive glass ${ }^{\circledR}$
}

\author{
** Said Shokry, MD; *Al Sayed Hossieni Al`Sayed, MD; *Mohammed Fatehy Zidan, MD; \\ **Adel Ahmed Hafez,MD;**Hanafi Mahmoud Abdulsalam,MD
}

\begin{abstract}
Background and objective: The aim of this study was to evaluate bioactive glass as an ideal material for the purpose of mastoid cavity elimination after mastoid surgery to avoid mastoid cavity problems.

Materials and methods: In 20 patients diagnosed as cholesteatoma or chronic unsafe ear, we used different surgical techniques according to pathology and situation during surgical exploration, basically adhering to standard principles of eradicating disease in chronic unsafe ear. After performing the canal wall down (CWD) or the canal wall up (CWU) technique, mastoidectomy was followed by obliteration of mastoid cavity by particulate form Bioglass ${ }^{\circledR}$. Cases were divided according to operative procedures, type of reconstruction and material used into 3 groups A- Canal wall up mastoidectomy followed by obliteration of mastoid cavity by particulate form Bioglass ${ }^{\circledR}$. B- Canal wall down mastoidectomy followed by reconstruction of posterior meatal wall and obliteration of mastoid cavity by particulate form Bioglass ${ }^{\circledR}$. C- Canal wall down mastoidectomy followed by reconstruction of posterior meatal wall by conchal cartilage and obliteration of mastoid cavity by Bioglass®.

Results: Bioactiveglass paste is very effective for mastoid obliteration in the three groups with good integration to the surrounding tissues either connective tissue, bone, meninges or lateral dural sinus without any adverse reaction on the dura even with contact to Bioglass ${ }^{\circledR}$. Infection was seen in 2 cases (10\%), however was readily controlled by topical application of antibiotics daily for one week. In both cases no extrusion of the material occurred.

Conclusion: The successful formation of bone with elimination of mastoid cavity problems proved that using Bioglass is appropriate for performing clinical mastoid obliteration.

Key words:mastoid cavity Problems, Mastoid obliteration, Bioactive glass
\end{abstract}

\section{Introduction}

The ideal surgical procedure for cholesteatoma should satisfy the following conditions: first, the creation of a dry safe ear; second, the prevention of recurrence; and the reestablishment of a wellaerated middle ear with a properly functioning sound-conducting mechanism. The choice of surgical technique is mainly based on the propagation of the disease, Eustachian tube function, and the status of other middle ear structures.

Over the past years, the gold standard for management of cholesteatoma has been the canal wall down technique (CWD). Removal of the posterior canal wall allows exposure of the entire epitympanum and middle ear and ensures

*ENT Depart, Faculty of Medicine, Al Azhar University Cairo complete disease eradication. However, this technique has several problems such as the accumulation of debris, requiring periodic cleaning and water restriction; dizziness; and difficulty with fitting in a hearing aid (Birzgalis et al, 1994). With the canal wall up technique (CWU) these problems can be avoided, although the rate of residual and recurrent disease tends to be higher than when using the CWD (Meuser, 1985).

Various factors can contribute to a problematic cavity, namely a large cavity, high facial ridge, narrow meatus, dependent mastoid tip, residual disease and an open middle ear space. Each of these problems is amenable to surgical correction. 
** Hearing and Speech Institute _Egypt

However many techniques have been used since the beginning of last century for mastoid obliteration to reduce the cavity size. Various autologous materials have been used, such as muscle, fat, cartilage, musculoperiosteal flaps, bone chip and bone pate. There are technical problems with each, most commonly the variable resorption that occurs postoperatively leading to an unpredictable final cavity size. There is also the theoretical risk of reimplanting cholesteatoma if bone pate is used for obliteration.

Different biomaterials have been tried on the basis that they should be non-resorbable, nonreactive and integrate. Carbonated calcium phosphate (CCP) bone cements have many features useful in otologic surgery. These cements harden within minutes in a moist environment, are non-toxic and non-exothermic, and, like hydroxyapatite, have the potential for osseointegration and remodeling.

This study aimed to assess the long-term effectiveness of Bony glass $\AA$, Bioglass $\AA$ "45S5", as a suitable biomaterial for mastoid obliteration. Bioglass ${ }^{\circledR}$ "45S5" is a bioactive glass ceramics which is composed of $45 \%$ silicone dioxide, $24.5 \%$ calcium oxide, $24.5 \%$ sodium dioxide and $6 \%$ phosphorous pentoxide (Lossdorfer et al 2004).

The aim of using of such materials for the graft is to promote adequate bone regeneration at the defective site by acting as a scaffold for osseous growth. Bony glass ${ }^{\circledR}$ resorbs and regenerates bone in 3 to 6 months depending on the site of implantation, the size of the bony defect and the age of the patient. Many tests showed that Bioactive glass ${ }^{\circledR}$ was neither carcinogenic nor toxic to any of the tissues or systems with which it was in contact (Wilson et al, 1981).

\section{PATIENTS AND METHODS}

This study is a prospective study at a tertiary care hospitals looking at the use of Bioglass ${ }^{\circledR}$ for the obliteration of mastoid cavities in 20 patients. We conducted on 20 patients with chronic suppurative otitis media (7 with granulation tissue and 13 with cholesteatoma). They were suffering from chronic discharging ear. All cases were subjected to mastoid surgery with complete eradication of the disease. The patients presented to outpatient clinic of Hearing and Speech Institute and Al'Zahra University Hospital Oto-Rhino-Laryngology department. The age ranged from 10 to 50 years. They had no previous ear surgeries. Cases in which complete eradication of disease was not certain (e.g. extensive granulation on top of cholesteatoma) were not subjected to obliteration and accordingly excluded from the study.

\section{All patients were subjected to Pre-operative assessment:}

Clinical evaluation: includes detailed history of the disease (onset, duration, course, frequency of exacerbation, development of any complications and history of previous surgery of the ear); Examination of nose and throat; Otoscopic and microscopic examination ; Audiologic assessment ; Plain x-ray on both mastoids; Culture and sensitivity for ear discharge; Systemic examination to assess surgical fitness and finally Preparation for mastoid operation. Laboratory investigations: Includes complete blood picture; Bleeding and clotting times; Random blood sugar; Urea and creatinine levels; SGOT and SGPT levels. ECG and Plain chest x-ray.

\section{Operative procedures}

Cases were operated upon during the period from April 2006 to April 2007; with Bioglass ${ }^{\circledR}$ used in particulate form which presented in vials containing $1 \mathrm{gm}$ of sterilized Bioglass ${ }^{\circledR}$. 


\section{According to the operative procedures, cases were classified into three groups:-}

Group A: Six cases with canal wall up mastoidectomy followed by obliteration of mastoid cavity by particulate form Bioglass ${ }^{\circ}$.

1. Using a retroauricular incision, a canal wall-up mastoidectomy was performed; then a large graft $3 X 3$ $\mathrm{cm}$ from temporalis fascia was taken. Large Palva flap anteriorly based to provide a good cover of the filling material in the cavity. Using a large cutting burr, the bone above and behind the external auditory meatus (Mc Ewen's triangle) was gradually excavated to open the antrum, the wall of the cavity was gradually widened until the lateral sinus plate, dural plate, and the dome of the lateral semicircular canal and short process of the incus were identified. Working from the antrum; all air cell were exenterated until the white bony plates over the middle and posterior cranial fossae were exposed. Any diseased tissues were removed. During the whole process of excavation, the bony posterior meatal wall was thinned, but kept intact (Canal wall up mastoidectomy).

2. The annulus was elevated and any diseased tissue in the middle ear was removed. Gelfoam was applied to the middle ear, then the remanent of the drum was grafted with temporalis fascia and gelfoam was applied above the graft in the ext canal. A small piece of gelfoam enough to close the aditus ad antrum prevents particulate Bioglass ${ }^{\circledR}$ from escaping to the middle ear.

3. We prepared the filling by mixing the particulate form Bioglass ${ }^{\circledR}$ with venous blood. The mastoid cavity has been filled with the mixture. The particulate form Bioglass ${ }^{\circledR}$ was covered by a large piece of gelfoam before closure of the wound to prevent incorporation of particles of Bioglass ${ }^{\circledR}$ inbetween the edges of the wound. Post auricular incision was closed in layers with interrupted sutures.

Group B: Nine cases with canal wall down mastoidectomy followed by reconstruction of posterior meatal wall and obliteration of mastoid cavity by particulate form Bioglass ${ }^{\circledR}$

1. Using a retroauricular incision, a canal wall-down mastoidectomy was performed. The skin of the external meatus was preserved as much as possible.

2. Combined reconstruction of the posterior meatal wall and obliteration of mastoid cavity by particulate form Bioglass ${ }^{\circledR}$ was done in one step as follows:-

*A foil template which gives accurate measurement and degree of curvature of the posterior meatal wall has been used to get the template. This foil template has been used to keep the particulate Bioglass ${ }^{\circledR}$ in the desired place. Apiece of cotton soaked in saline was applied in the middle ear and external canal to maintain the position of the foil template.

*The prepared mixture of Bioglass ${ }^{\circledR}$ particles and blood was used to fill the mastoid cavity until the posterior meatal wall has been reconstructed. The piece of cotton in the middle ear was then removed.

3. Gelfoam was applied to the middle ear.Then a temporalis graft was applied below the drum remnant with extension to cover the Bioglass ${ }^{\circledR}$. Gelfoam was applied in sufficient amount above the graft in the renewed ext. canal to support the Bioglass ${ }^{\circledR}$ particulates in place then the foil template was removed.

Group C: Five cases with canal wall down mastoidectomy. This is followed by reconstruction of posterior meatal wall by conchal cartilage and obliteration of mastoid cavity by Bioglass ${ }^{\circ}$.

1. Using a retroauricular incision, a canal wall-down mastoidectomy was performed. The skin of the external meatus was preserved as much as possible, just like in group B. Then reconstruction of the posterior meatal wall by conchal cartilage was done by Conchal cartilage was adjusted, by scalpel knife and trimmed to fit the wall defect and slipped between two grooves done by fine diamond burr at the site of the superior and inferior buttresses.

2. Gel foam was applied to the middle ear, and then a temporalis graft was applied below the drum remnant. Gelfoam used again to cover the graft.

3. The prepared Bioglass ${ }^{\circledR}-$ blood mixture was used for obliteration of the mastoid cavity. The Operative steps in group $\mathrm{C}$ are illustrated in the following figures (1-6).

\section{Follow up}


-Regular follow up every two weeks during the first two months postoperative then every month during the next six months has been done.

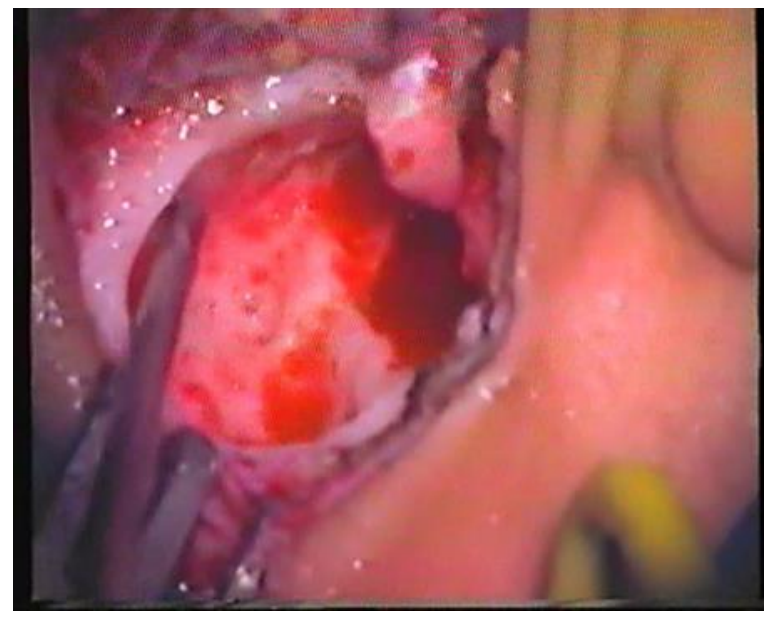

Figure 1. Mastoid cavity after completion of CWD mastoidectomy

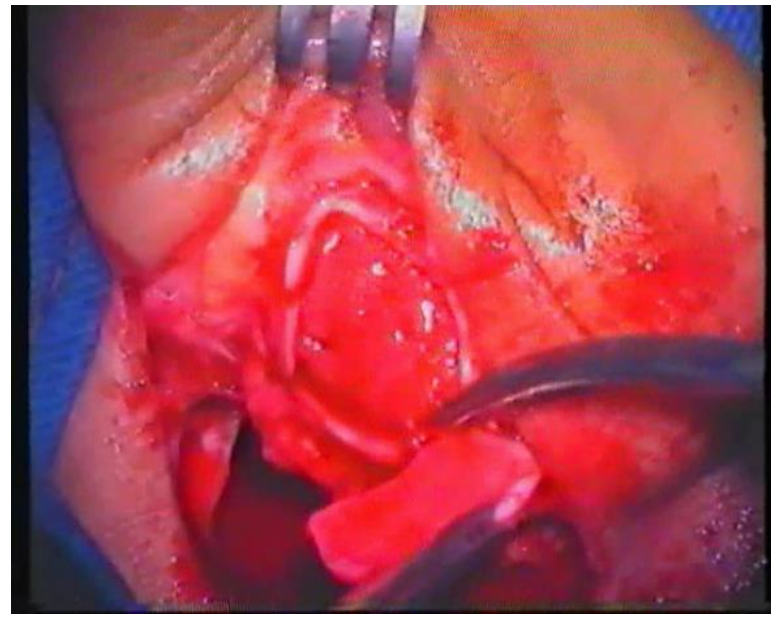

Figure 2. Conchal Cartilage being harvested for rebuilding of the Posterior meatal wall

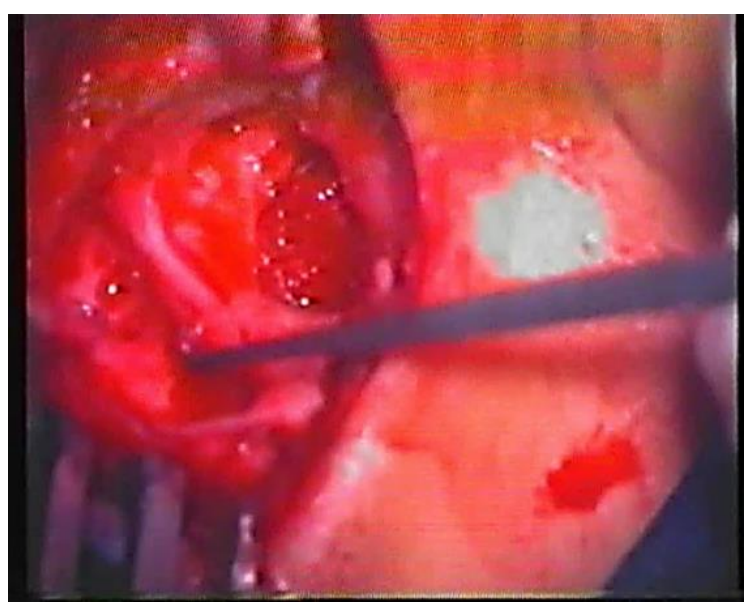


Figure 3. Fitting of the conchal cartilage between the two grooves which done by fine diamond burr, at the site of the superior and inferior buttresses.

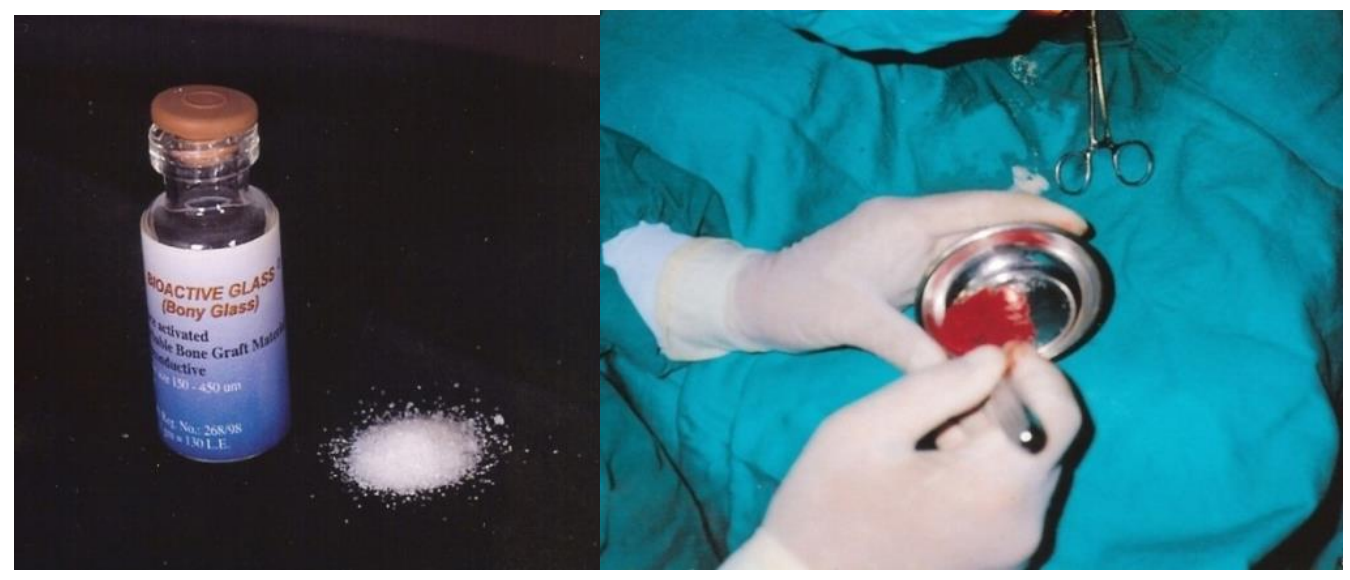

Figure 4. mixing Bioglass ${ }^{\circledR}$ "45S5 with venous blood to form a paste : Bioglass ${ }^{\circledR}$ "45S5" is a Bioactive glass ceramics which is composed of $45 \%$ silicone dioxide, $24.5 \%$ calcium oxide, $24.5 \%$ sodium dioxide and $6 \%$ phosphorous pent oxide

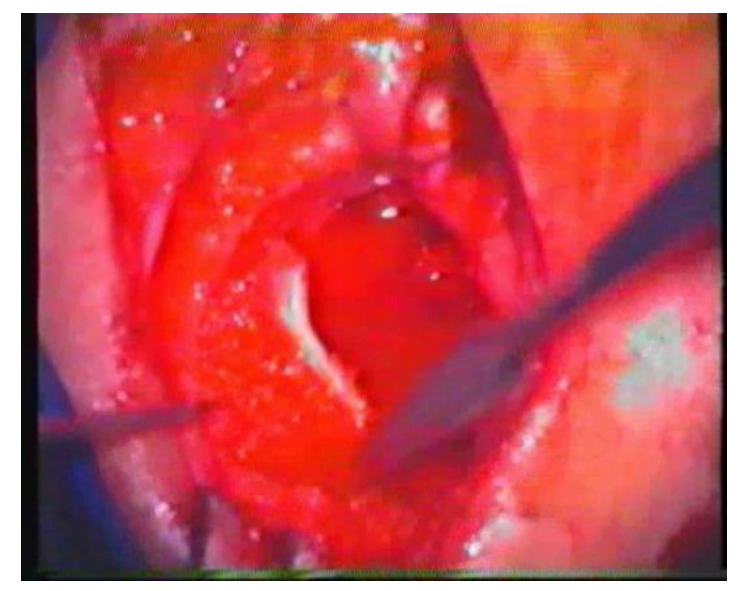

Figure 5. The prepared Bioglass ${ }^{\circledR}$-blood mixture was used for obliteration of the mastoid cavity behind the reconstructed posterior meatal wall 


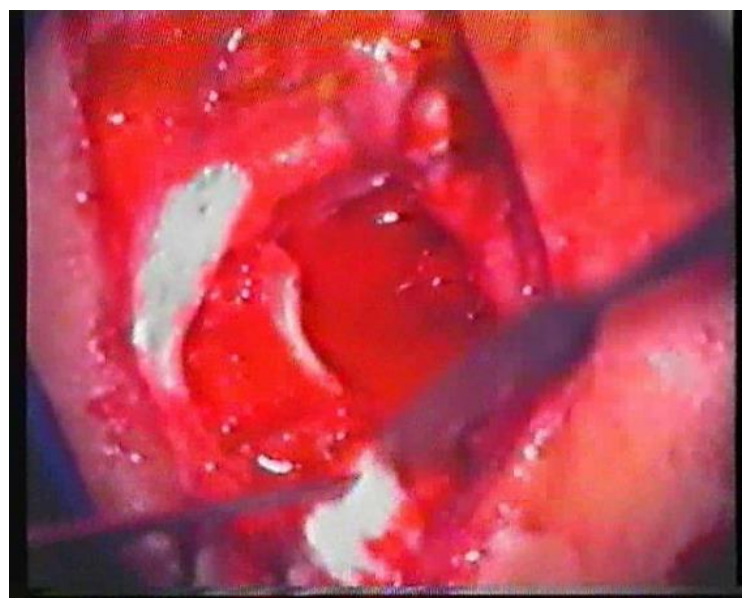

Figure 6. Gelfoam is layered over the bioglass_blood paste to isolate from soft tissues before Suturing

\section{Results}

Cases were divided according to operative procedures, type of reconstruction and material used into 3 groups

Table (1): Patient data regarding groups, age, sex, and pathology, contact of material with dura and lateral sinus and complications.

\begin{tabular}{|c|c|c|c|c|c|c|}
\hline Groups & $\begin{array}{r}\text { Case } \\
\text { No. }\end{array}$ & $\begin{array}{l}\text { Age } \\
(y s)\end{array}$ & Sex & Pathology & $\begin{array}{c}\text { Contact of } \\
\text { Bioglass } ® \text { with } \\
\text { Dura and lateral } \\
\text { sinus }\end{array}$ & $\begin{array}{l}\text { Complicati- } \\
\text { ons }\end{array}$ \\
\hline $\begin{array}{l}\text { Group A:CWU Mastoidectomy } \\
\text { followed by obliteration only by } \\
\text { Bioglass ( } 6 \text { cases) }\end{array}$ & $\begin{array}{l}1 \\
2 \\
3 \\
4 \\
5 \\
6\end{array}$ & $\begin{array}{l}20 \\
37 \\
50 \\
17 \\
24 \\
13\end{array}$ & $\begin{array}{l}\text { Female } \\
\text { Female } \\
\text { Male } \\
\text { Female } \\
\text { Female } \\
\text { Male }\end{array}$ & 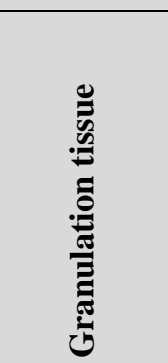 & & Infection \\
\hline
\end{tabular}




\begin{tabular}{|c|c|c|c|c|c|c|}
\hline $\begin{array}{l}\text { Group B: CWD Mastoidectomy } \\
\text { with reconstruction of posterior } \\
\text { meatal wall and obliteration of } \\
\text { mastoid by Bioglass. ( } 9 \text { casea) }\end{array}$ & \begin{tabular}{|l|}
7 \\
8 \\
9 \\
10 \\
\\
11 \\
12 \\
13 \\
14 \\
15
\end{tabular} & $\begin{array}{l}26 \\
31 \\
29 \\
40 \\
\\
10 \\
17 \\
22 \\
18 \\
39\end{array}$ & $\begin{array}{l}\text { Male } \\
\text { Male } \\
\text { Male } \\
\text { Female } \\
\text { Male } \\
\text { Male } \\
\text { Female } \\
\text { Female } \\
\text { Female }\end{array}$ & 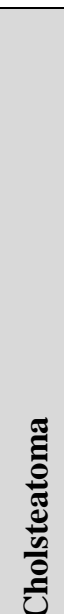 & $\begin{array}{l}\text { with dura } \\
\text { With dura and } \\
\text { lateral sinus }\end{array}$ & Infection \\
\hline $\begin{array}{l}\text { Group C: CWD Mastoidectomy } \\
\text { with reconstruction of posterior } \\
\text { meatal wall by conchal cartilage } \\
\text { and obliteration of mastoid by } \\
\text { Bioglass. ( } 5 \text { cases) }\end{array}$ & $\begin{array}{l}16 \\
17 \\
18 \\
19 \\
20\end{array}$ & $\begin{array}{l}24 \\
41 \\
19 \\
25\end{array}$ & $\begin{array}{l}\text { Male } \\
\text { Male } \\
\text { Male } \\
\text { Male } \\
\text { Female }\end{array}$ & & With dura & $\begin{array}{l}\text { Cartilage } \\
\text { extrusion }\end{array}$ \\
\hline
\end{tabular}

Table (2) distribution of studied group as regards pathology.

\begin{tabular}{|c|c|c|c|c|c|c|c|c|}
\hline \multirow{2}{*}{ Groups } & \multicolumn{2}{|c|}{ Group A } & \multicolumn{2}{c|}{ Group B } & \multicolumn{2}{c|}{ Group C } & \multicolumn{2}{c|}{ Total } \\
\cline { 2 - 9 } & No & $\%$ & No & $\%$ & No & $\%$ & No & $\%$ \\
\hline Granulation tissue & 6 & $100 \%$ & 1 & $11.11 \%$ & - & - & 7 & $35 \%$ \\
\hline Cholesteatoma & - & - & 8 & $88.88 \%$ & 5 & $100 \%$ & 13 & $65 \%$ \\
\hline Total & 6 & $100 \%$ & 9 & $100 \%$ & 5 & $100 \%$ & 20 & $100 \%$ \\
\hline
\end{tabular}

The pathology detected during operation, 7 cases (35\%) with extensive granulation tissue \{all cases of group A and 1 case in group B \} were found, whereas 13 cases (65\%) with cholesteatoma $\{8$ cases of group B and all cases of group $\mathrm{C}$ \} were found and none of group $\mathrm{A}$ were cholesteatoma (Graph1).

All cases of cholesteatoma have undergone canal wall down procedure for complete eradication of the disease and all cases of granulation tissue have undergone canal wall up procedure without fear of incomplete eradication of the disease except in one case transformed to CWD.

Bioglass ${ }^{\circledR}$ was in contact with dura in 2 cases (10\%) \{Cases No 10 from group B and case No 17 from group $\mathrm{C}$ (Table1) , and in contact to both dura and lateral sinus in another single case (5\%)\{Case No 13 from group B (Table1)\} without any adverse reaction on the dura. We found out that there was no adverse reaction on the dura due to contact with Bioglass ${ }^{\circledR}$ 


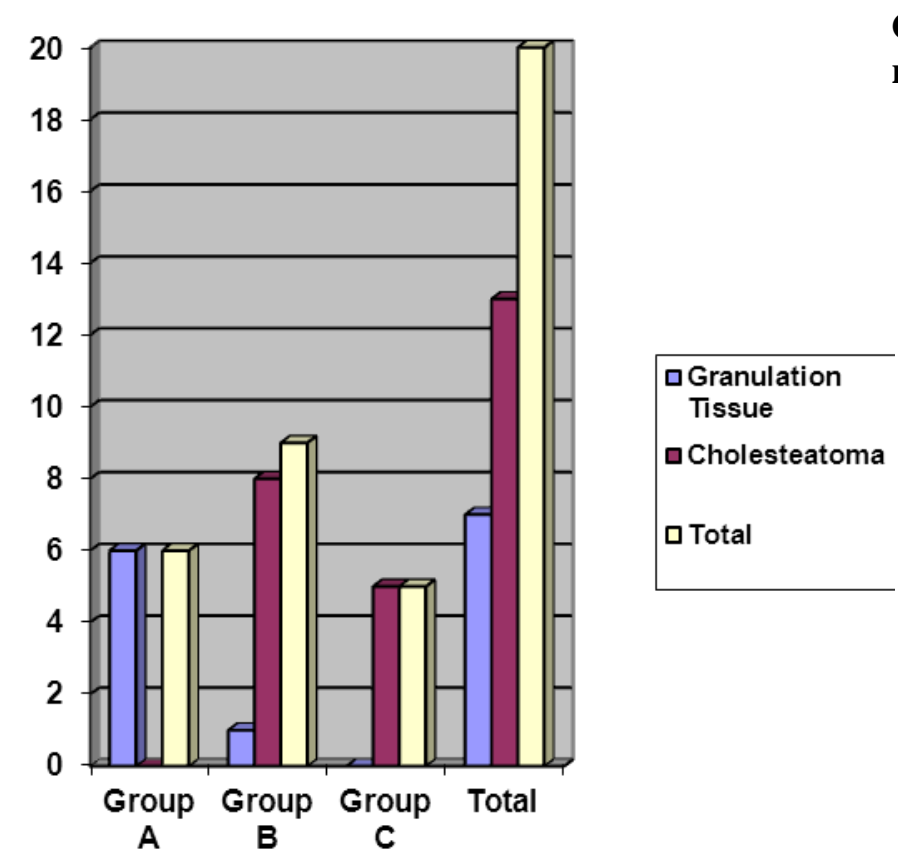

\section{Graph (1)-Distribution of studied groups as regards pathology}

Table (3): Postoperative problems in different mastoid obliteration groups

\begin{tabular}{|c|c|c|c|c|c|c|c|c|}
\hline \multirow{2}{*}{ Groups } & \multicolumn{2}{|c|}{ Group A } & \multicolumn{2}{|c|}{ Group B } & \multicolumn{2}{c|}{ Group C } & \multicolumn{2}{c|}{ Total } \\
\cline { 2 - 9 } & No & $\%$ & No & $\%$ & No & $\%$ & No & $\%$ \\
\hline Infection & 1 & 16.67 & 1 & $11.11 \%$ & - & - & 2 & $10 \%$ \\
\hline Extrusion of reconstructed cartilage of PMW & - & - & - & - & 1 & $20 \%$ & 1 & $5 \%$ \\
\hline Total & 1 & 16.67 & 1 & $11.11 \%$ & 1 & $20 \%$ & 3 & $15 \%$ \\
\hline
\end{tabular}

Two complications were encountered infection and cartilage extrusion. Infection occurred in two cases (one in group A No. 4 and the other in group B No. 8 (Table 3). This was discovered one week postoperative during removal of the pack and was controlled by topical antibiotics daily for one week. In both cases no extrusion of the material occurred. Extrusion of the conchal cartilage used in reconstruction of posterior meatal wall occurred in 1 case in group $\mathrm{C}$ one month post-operative (case No 18 - Table 1).

\section{Discussion}

Canal wall up (CWU) techniques preserve the anatomy of the posterior canal wall, eliminating the need for periodic bowl cleaning and avoiding the risk of recurrent bowl infection. However the recidivism rate may be as high as $36 \%$ in adults and $67 \%$ in children after CWU procedures (Shohet JA\& De Jong 2002). Surgical intervention is "closed" when afterwards there is no persistence of any communication between the external meatus, which remains more or less intact, and the antroattical cavities, which are trepanned (trephined) during the operation (Jansen, 1958). Nevertheless, the debate is still on due to new evidence, better imaging, hightech endoscopes and intraoperative use of facial nerve monitoring. 
However, Canal wall-down mastoidectomy is the most widely used surgical method worldwide. It is supposed to be easier, of shorter duration, necessitates less surgical experience than the CWU procedures, and has low recurrence and residual rate. CWD procedure is claimed to be the unique solution for cholesteatomas in an only - hearing ear and when there is a labyrinthine fistula (Hulka\&McElveen 1998). However, in a situation such as the only hearing ear surgery, Tu (2005) did not adopt CWD approach, except for special considerations.

Some surgeons propose a different procedure, the canal wall window (CWW) technique, which involves slitting the posterior canal wall. They claim that it provides good hearing results, especially in a young population who will bear the surgical outcome for many decades (Godinho et.al 2005).

Hopkin's wide-angle endoscopes are intraoperatively useful for checking areas that cannot be visualized with the microscope. Therefore, the use of endoscopes is supposed to reduce the residual cholesteatoma rate (Phelan et. al 2008). This leads Nikolopoulos and Gerbesiotis (2009) to revive and advocate the well-known approach of inside to outside chase of cholesteatoma sac, to find the mouth of the cholesteatoma sac, to follow it until the end, to totally remove it creating a small mastoid cavity after performing tympanoplasty. The procedure is progressive, anterior-to posterior dissection, exposing the cholesteatoma, thus creating atticotomy, atticoantrostomy and mastoidectomy. Following the cholesteatoma and removing as much bone as needed allows creating the smaller mastoid cavity possible. Ideally, the middle ear cleft should be left as an air containing cavity not open to the EAM.

Where there is an extensive mastoid involvement, the posterior meatal wall is totally removed and the facial ridge is taken down to the floor of the external auditory meatus (EAM); thus the mastoid cavity does not form an independent sump. HERE, bioactive glass can be invited to obliterate the resulting mastoid cavity after atticotomy, atticoantrostomy and mastoidectomy tailored surgery to avoid mastoid cavity problems.

The disadvantages of biological grafts, gave attention to the use of synthetic materials. The latter should have a high degree of biocompatibility, shouldn't be extruded or resorbed, easily measured, contoured and should provide predictable and consistent sound transmission (El-seifi and Fouad 1998). Bioglass $₫$ "45S5" is a bioactive glass ceramics which is composed of $45 \%$ silicone dioxide, $24.5 \%$ calcium oxide, $24.5 \%$ sodium dioxide and $6 \%$ phosphorous pentoxide (Lossdorfer et al 2004).

We therefore consider the bioactive glass to be a promising material as a bone substitute. In addition, using autologous cartilage to reconstruct the external auditory meatus is advantageous in some cases of Canal down (CWD) mastoidectomy to aid fashioning posterior meatal wall. In this study, the results were satisfactory. Moreover, there were no complications, such as hearing loss, vestibular dysfunction, cholesteatoma, or uncontrolled proliferation of granulation. As preliminary clinical report, our results indicate that Bioglass covered with gelfoam is likely to be useful for mastoid obliteration. However, we need to have a longer follow up to report more solid conclusion. We need further prospective case control study.

However, Obliteration may solve the problems of the CWD presented due to no posterior canal wall; with Bioglass obliteration, we expect much improvement in auditory rehabilitation in patients who have mixed hearing loss due to cholesteatoma and high frequency loss because of the changing of external auditory canal resonance after surgery (Gantz et al 2005).

Bioactive glass obliteration has various advantages in operations involving cholesteatoma. In addition to cholesteatoma, chronic otitis media with poor Eustachian tube function, adhesive otitis media, and a sclerotic mastoid cavity favorable to obliteration have also become indications for using this technique. 
Controversial Issues of this subject are still rising up.

One of the contraindications of reconstruction of the posterior meatal wall and/ or obliteration of mastoid cavity is the incomplete removal of the disease (Blak, 1995). So cases, in which complete eradication of the disease was not certain, were excluded from this study.

Different synthetic materials have been used in obliteration and reconstruction such as silicone, proplast, ionomer cement ceravital and hydroxyl apatite. These materials did not fulfill optimal criteriae and showed many disadvantages such as considerable foreign body reaction with silicone (Rosenblut et al., 1994) and dehiscence problems with proplast (Shea et al., 1984); Infection and encephalopathy with ionomer cement (Renard et al 1994) and absorption and lysis with ceravital (Reck, et al., 1988; El-Seifi and Fouad, 1998).

Reported complications after obliteration with synthetic material include: infection, extrusion, resorption, myringitis, granulation tissue formation, recurrence of discharge, retraction pocket formation, recurrence of cholesteatoma, defect in external canal reepithelialisation, canal dehiscence and post-auricular fistula (Black, 1995). Our study showed infection in 2 cases and extrusion of the cartilage in 1 case while myringitis, and canal dehiscence or granular extrusion was not encountered.

Hydroxylapatite is the material most widely utilized as it has the best results among all synthetic materials regarding to its bioactivity and composition which resemble bone tissue (De Groot et al, 1988 \& Ricci; 1992). However, a comparative study of particulate Bioglass ${ }^{\circledR}$ to hydroxylapatite as a bone graft substitute in animal models concluded that the Bioglass ${ }^{\circledR}$ was superior to hydroxylapatite because the latter showed encapsulation by fibrous connective tissue, while Bioglass ${ }^{\circledR}$ showed true integration of the new bone without any encapsulation. In Oonishi study hydroxylapatite disappeared faster than Bioglass $®$, so that the empty spaces were not completely filled with new bone formation. Moreover, the speed of bone growth around the
Bioglass ${ }^{\circledR}$ was much faster and bone formation was much denser and more mature than with hydroxylapatite (Oonishi et al., 1997).

Oonishi Radio- Histological Animal Studies on guinea pig confirmed by (Jang, et al., 2007) showed hyperintense areas of new bone formation in CT scans. Then Histological evidence of new bone formation was observed in the implant specimens that included: active osteoblasts, osteocytes, chondrocytes and osteoid tissue. There was a definite bond between the implant and the bone interface at the areas of new bone formation. No inflammatory or foreign body reactions, caused by the Bioactive glass ${ }^{\circledR}$ ceramic particle implantation, were observed in the surrounding tissue.

In our study all 6 cases with obliteration of the cavity after canal wall up mastoidectomy showed neither retraction pocket formation nor recurrent infection. Palva and Virtanent 1981; Vartianen and Harma, 1987 concluded in their comperative studies between obliterated and non-obliterated cavities after canal wall up mastoidectomy that the obliterated cavities were superior regarding to control of infection, hearing improvement and protection against the formation of future retraction pocket in ears with poor tubal function.

Bellantone et al., (2000); Jones et al (2006); Lepparanta et al., (2007); Munukka et al., (2007); Waltimo et al, (2007) referred to the antibacterial effect of Bioactive glass ${ }^{\circledR}$ which seems to be true since the 2 cases with infection in our study showed no granular extrusion and complete bone formation occurred 6 months later despite post-operative infection.

Drawbacks of reconstruction of posterior meatal wall by conchal cartilage were the instability, time consuming and subjecting the facial nerve to surgical trauma during buttresses grooving as reported by Black (1995); also Dornhoffer and Simmons, 2003 reported inadequate cartilage, excessive curvature, the somewhat tedious process of cutting the cartilage making a good fit impossible. For avoidance of these drawbacks in the cases which were obliterated and 
reconstructed, the use of particulate Bioglass $®$ was preferred. This technique is faster, easier, makes the particles adherent to each other like one mass so extrusion became difficult and buttresses grooving with their complications were avoided. This was achieved in all cases which were reconstructed and obliterated by particulate form Bioglass $®$.

Black (1995) showed that the direct contact of external auditory canal skin with hydroxylapatite used in reconstruction of posterior meatal wall is followed by the formation of granulation tissue. We inserted gelfoam between the particles of Bioglass ${ }^{\circledR}$ and the post-auricular incision before closure of the wound thus, no granulation or myringitis was formed in the external ear and the post-auricular incision showed good healing in all cases.

In general, our results are comparable to previous results of Bioglass ${ }^{\circledR}$ application in different sites of human body (Schepers et al., 1993; shapoff, 1997; Stanley et al., 1997; Della santina et., al 2006; Tuusa et al., 2007). In our study material probably results in new bone formation in all cases with, no complications were detected in cases where it became in contact with dura and lateral sinus and no extrusion to particles of Bioglass ${ }^{\circledR}$ in all cases even with cases in which infection was occurred.

\section{Conclusion}

Our study showed that CWR and mastoid obliteration using Bioactive glass ${ }^{\circledR}$ is a technique that facilitates exposure of the middle ear and ensure complete removal of cholesteatoma. Reconstruction of the posterior canal wall with conchal cartilage or Bioactive glass ${ }^{\circledR}$ recreates the normal external canal anatomy and allow for elimination of the mastoid bowl. It is suitable for most patients with chronic otitis media with cholesteatoma, including adults and children.

Our study showed also that the Bioglass ${ }^{\circledR}$ material is bioactive, biocompatible, provides favorable healing, resist infection, easily prepared and placed, and probably provides new bone formation without any encapsulation. All these findings demonstrate that Bioglass ${ }^{\circledR}$ is a highly suitable synthetic material for reconstruction and/or obliteration in temporal bone surgery.

\section{References}

1. Bellantone M, Coleman NJ and Hench, LL (2000): Bacteriostatic action of a novel four-component bioactive glass.J. Biomed Mater Res. Sep 5; 51 (3):484-490.

2. Birzgalis AR, Farrington WT, O'Keefe L. (1994): Reconstruction of discharging mastoid cavities using the temporalis myofacial flap. Clin Otolaryngol Allied Sci; 19:70-2.

3. Black B (1995): Mastoidectomy elimination. Laryngoscope (Supple76); 105:1-30

4. De Groot K (1988): Degradable ceramics. In: Biocompatibility of clinical implants materials, Vol. I edited by D. F. Williams Boca Raton, Fla: Press. Pp (19):9-224.

5. Della Santina CC and Lee SC (2006): Ceravital reconstruction of canal wall down mastoidectomy: long-term results, Arch Otolaryngol. Head Neck Surg. 132 (June 6) 617-623.

6. Dornoffer, J and Simmons, O (2003): Canal wall reconstruction with mimx hydroxylapatite cement: Results in an animal modile and case study. Laryngoscope 113: 2123-2128.

7. El-Seifi A and Fouad B (1998): Long-term fate of plastipore in the middle ear. ORL 60: 198-201.

8. Gantz BJ, Wilkinson EP, Hansen MR (2005): Canal wall reconstruction tympanomastoidectomy with mastoid obliteration, Laryngoscope 115 (October 10) 1734-1740.

9. Godinho RA, Kamil SH, Lubianca JN, Keogh IJ, Eavey RD (2005): Pediatric cholesteatoma: canal wall window alternative to canal wall down mastoidectomy, Otol. Neurotol. 26 (May 3) 466-471. 
10. Hulka GF, McElveen JT (1998) : A randomized, blinded study of canal wall up versus canal wall down mastoidectomy determining the differences in viewing middle ear anatomy and pathology, Am. J. Otol. 19 (September 5) 574- 578.

11. Jang CH, Cho YB and Bae CS (2007): Evaluation of bioactive glass for mastoid obliteration: A guinea pig model. In vivo. Jul-Aug; 21(4):651-5.

12. Jansen C (1958): Uber radical operation and tympanoplastic sits. Ber. forbid. Arztekamm, Februau 18: 1958. Quoted from Protmann, M. (1968): Open or closed technique in surgery of the middle ear. Ann. Otol. Rhinol. Laryngol. 77:927-937.

13. Jones JR, Ehrenfried LM, Saravanapavan P, Hench LL (2006): Controlling ion release from bioactive glass foam scaffolds with antibacterial properties. J Mater sci Mater Med Nov; 17(11):989-96. Epub 2006 Nov 22.

14. Lepparanta O, Vaahtio M, Peltola T, Zhang D, Hupa L, Hupa M, Ylanen H, Salonen JI, Viljanen MK, Eerola E (2007): Antibacterial effect of bioactive glass on clinically important anaerobic bacteria on vitro. J Mater Sci Mater Med. Jul 10; (Epub a head of print).

15. Lossdorfer S, Schwartz, Lohmann CH, Greenspan DC, Ranly DM, Boyan BD (2004): Osteoblast response to bioactive glass in vitro correlates with inorganic phosphate content.Biomaterials. Jun; 25(13)2547-55.

16. Munukka E, Lepparanta O, Orkeamaki M, Vaahtio M, Peltila T, Zhang D, Hupa L, Ylanen H, Salonen JI, Viljanen MK , Eerola E (2007) : Bactericidal effect of bioactive glasses on clinically important aerobic bacteria. J Mater Sci Mater Med. Jun 14; (Epub a head of print)

17. Nikolopoulos TP, Gerbesiotis P (2009): International Journal of Pediatric Otorhinolaryngology $73: 1222-1227$

18. Oonishi H; Kushitani S, Yasukawa E, Iwaki, H, Hench, LL, Wilson J, Tsuji E and Sugihara T (1997): Particulate bioglass compared with hydroxyapatite as bone graft substitute. Clinical Orthopaedics and Related Reasearch.334:316-325.

19. Palva $T$ and Virtanent $H$ (1981): Ear surgery and mastoid air cell system. Arch. Otolaryngol. 107:71-73.

20. Phelan E, Harney M and Burns H (2008): Intraoperative findings in revision canal wall down mastoidectomy, Ir. Med. J. 101 (January 114.

21. Reck R, Storkel S and Meyer A (1988): Bioactive glass ceramics in middle ear surgery. Annals of the New York Academy of Sciences, 523,100-106.

22. Renard JL, Felten D and Bequet D (1994): Post otoneuro surgery aluminium encephalopathy. Lancet, ii, 63-64.

23. Ricci JL, Blumenthal NC, Spivak JM, and Alexander $H$ (1992): Evaluation of a low calcium phosphate particulate implants material: Physical chemical properties and in vivo bone response, $\mathrm{J}$ Oral Maxillofac surg 50, 969-978.

24. Rosenblunt B, Ahlvin RC, and Carr CD (1966): Silicone implants in the mastoid portion of the temporal bone. Ann Otol Rhino Laryngol, 75: 889-892.

25. Shapoff CA, Alexander, DC and Clark AE (1997): Clinical use of a bioactive glass particulate in the treatment of human osseous defects. Compandium. 18:352-363

26. Schepers EJG, Ducheyne P, Barbier L and Schepers $S$ (1993): Bioactive glass particles of narrow size range: A new material for the repair of bone defects, Int. Dentistry, 2, 3:151-156.

27. Shohet JA, de Jong AL. (2002): The management of pediatric cholesteatoma. Otolaryngol Clin North Am 35:841-851

28. Stanley HR, Clark AE, Hench LL and Bete JJ (1997): Using 45S5 Bioglass cones as endosseous ridge maintenance implants to prevent alveolar ridge resorption: A 5- years evaluation, The International Journal of Oral and Maxillofacial Implants, 12:95-101. 
29. Tu TY (2005): Cholesteatoma Surgery in Pneumatized and Non-pneumatized Temporal Bones J Chin Med Assoc • October $2005 \cdot \operatorname{Vol} 68 \cdot$ No 10

30. Tussa SM, Peltola MJ, Tirri T, Lassila LV and Vallittu PK (2007): Frontal bone defect repair with experimental glassreinforced composite with bioactive glass granule coating. J. Biomed Mater Res B Appl Biomater. Jul; 82(1):149-55.

31. Vartianen E and Harm R (1987): Mastoid obliteration in intact canal wall. Clin. Otolaryngol, 12: 327-329.

32. Waltimo T, Brunner TJ, Vollenweider M, Stark WJ and Zehnder M (2007):
Antimicrobial effect of nanometric bioactive glass 45S5. J Dent Res. Aug; 86(8):754-7

33. Wilson J, Clark AE and Hall $M$ et al. (1993): Tissue response to bioglass endosseous ridge maintenance implants. J. Oral Implantol. (19):295.

Correspondence: Al`Sayed Hossieni Al'Sayed, MD, Cairo, Egypt

Mobile: 01001640941

Financial Disclosure: None.

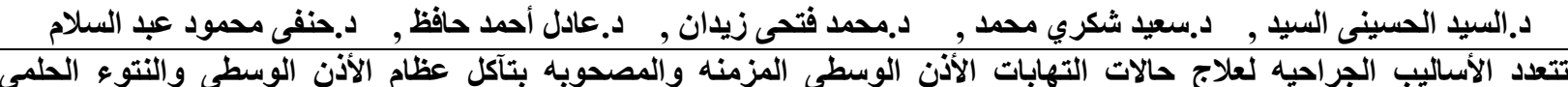

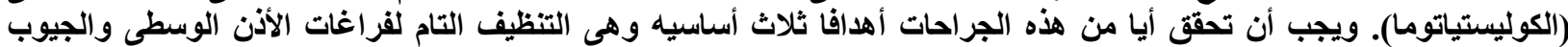

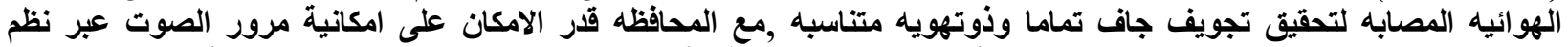

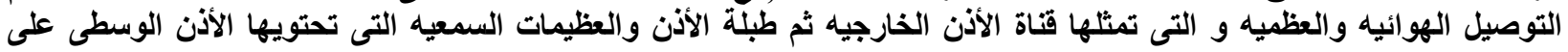

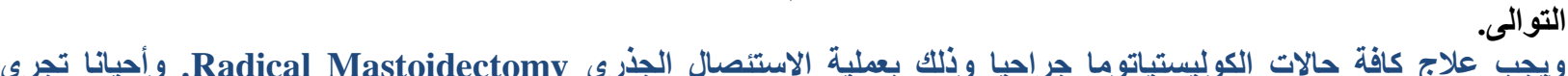

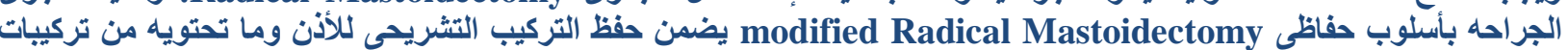

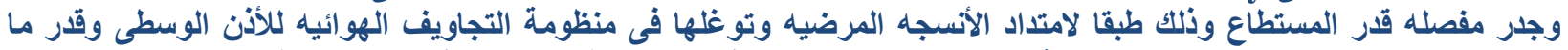

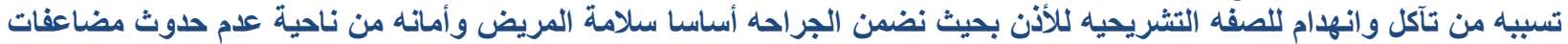
أو انتشار للمرض والمحافظه على حياته. وهذا التوع من الجراحات التحفظيه يمكن إجراؤه بشروط تمليها حالة الأنسجه المرضيه 
ومدى انتثار ها وتظلظلها كما أسلقا وبالإضافه الى طبيعة المريض وثثقافته وإمكانية المتابعه على فترات متقاربه ولعدة سنوات لضمان

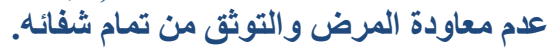

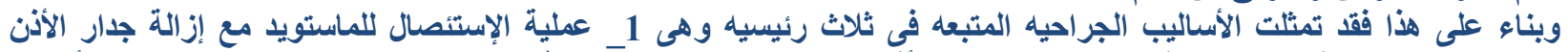

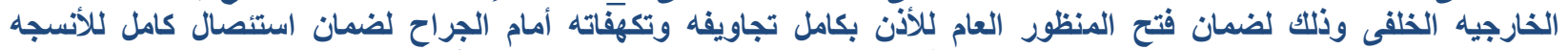

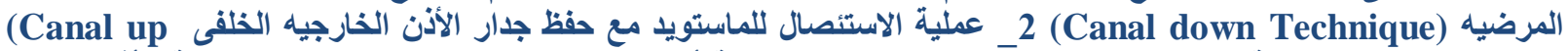

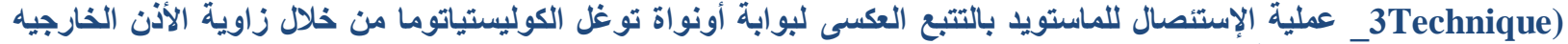

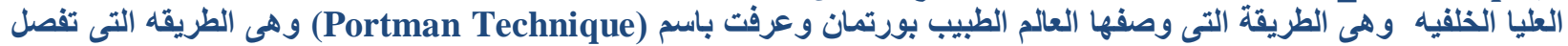

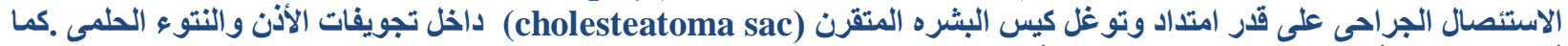

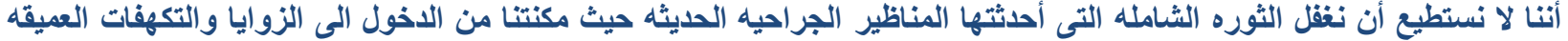

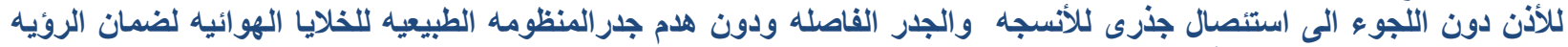

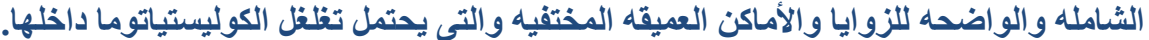

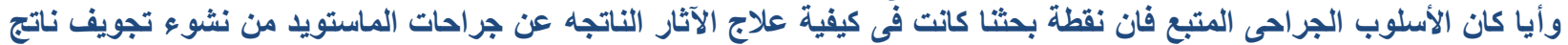

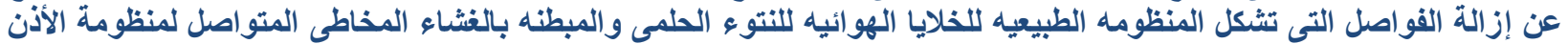

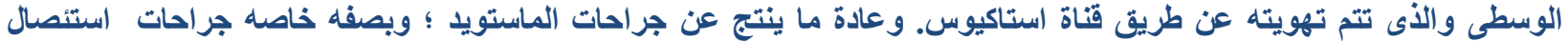

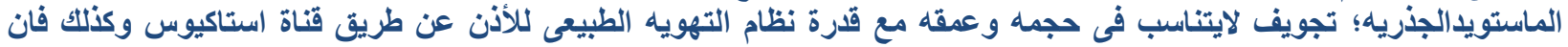

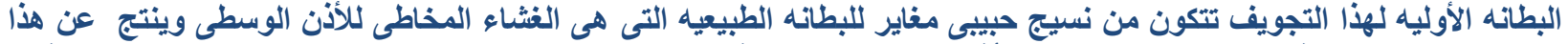

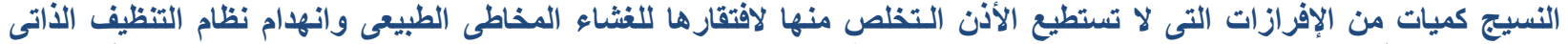

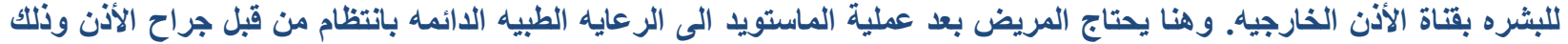

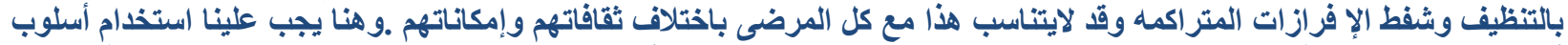

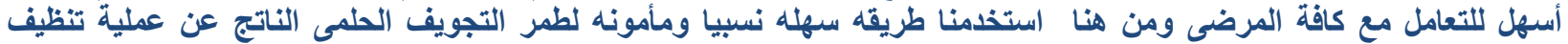

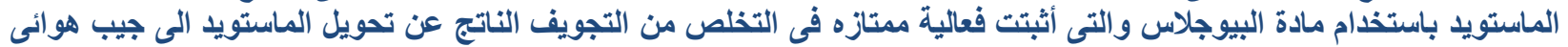

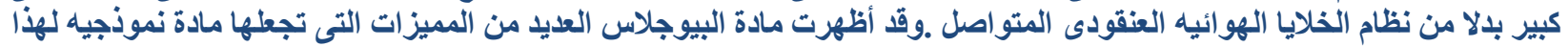

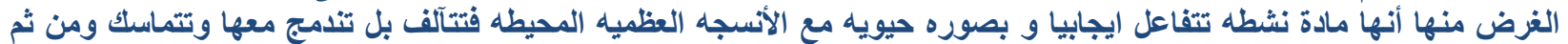

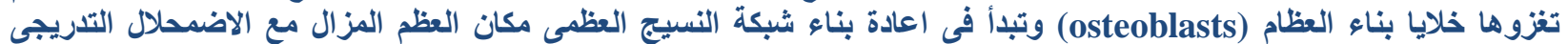

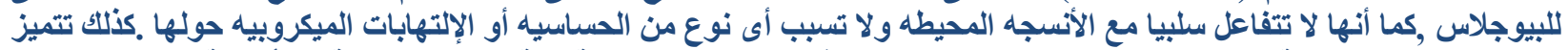

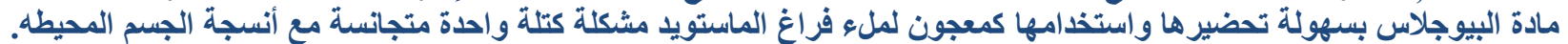

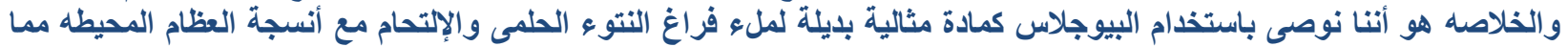

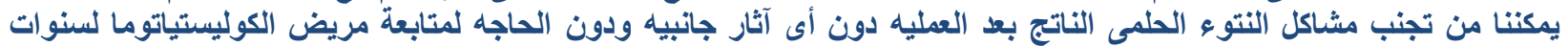
طويله أوبصفة دائمة بعد عمليات الماستويد. 